THE RING 32, 1-2 (2010) DOI 10.2478/v10050-010-0004-y

\title{
TIMING, AGE CLASSES AND WATER-CROSSING \\ BEHAVIOUR OF BLACK KITES (Milvus migrans) DURING SPRING MIGRATION ACROSS THE CENTRAL MEDITERRANEAN
}

\author{
Michele Panuccio and Nicolantonio Agostini
}

\begin{abstract}
Panuccio M., Agostini N. 2010. Timing, age classes and water-crossing behaviour of Black Kites (Milvus migrans) during spring migration across the Central Mediterranean. Ring 32, 1-2: 55-61.

The main migratory passage of Black Kites across the Mediterranean Sea occurs at the Strait of Gibraltar, where the migration peak is observed in early March. Conversely, in the Central Mediterranean the migration of this species is scarce during the supposed peak period, while hundreds of individuals are observed migrating later in the season, mostly in April and May. In the present study we investigate the spring migration of Black Kites at two sites of the Central Mediterranean, the island of Ustica and the Strait of Messina. Timing, age classes and water-crossing behaviour of this species suggest that large numbers of non-breeders use this route during spring. However, a peculiar migration timing of breeding pairs belonging to the Italian population cannot be excluded.
\end{abstract}

M. Panuccio, Università degli Studi di Pavia, Dipartimento di Biologia Animale, Via Ferrata 1, 27100 Pavia, Italy; N. Agostini, MEDRAPTORS (Mediterranean Raptor Migration Network), Via Carlo Alberto 4, 89046 Marina di Gioiosa Jonica, Italy

Key words: Black Kite, Milvus migrans, migration, water-crossing, Mediterranean Sea.

\section{INTRODUCTION}

During spring migration European raptors use different flyways to reach their breeding grounds from wintering territories located in Africa. Broad-winged raptors, like eagles and buzzards, concentrate in places where the distance between Africa and Europe is narrower (the Strait of Gibraltar and Bosporus), while other species with relatively long wings, like Circus spp., cross the Mediterranean on a wide front being more likely than broad-winged raptors to use powered flight over sea (Zalles and Bildstein 2000, Agostini 2005, Agostini and Panuccio 2010). Black Kites show intermediate behaviour between eagles and harriers: in fact, although concentrations 
of individuals are observed every spring at the Strait of Gibraltar, hundreds of Black Kites undertake long sea crossings in the Central Mediterranean region through the Channel of Sicily and the Tyrrhenian Sea (Agostini and Duchi 1994, Agostini and Logozzo 1998, Panuccio et al. 2004, Mellone et al. 2007). At the Strait of Gibraltar Black Kites migrate mostly in early spring peaking during the first half of March (Finlayson 1992). Conversely, in the Central Mediterranean area the passage in early March does not exist while hundreds of birds are observed migrating later in the season (Agostini 2002). It is supposed that birds crossing the Central Mediterranen belong to the population breeding in Italy, estimated at 700-1200 pairs (Agostini and Malara 1997, Agostini 2002, BirdLife 2004). This paper provides a comparative study on the spring migration of this species at two sites in southern Italy, the island of Ustica and the Strait of Messina, concentrating on timing, age classes and water-crossing behaviour.

\section{STUDY AREA AND METHODS}

At the island of Ustica observations were made between 22 March and 20 May 2002. Ustica is a small island $\left(8.5 \mathrm{~km}^{2}\right)$ located about $60 \mathrm{~km}$ north of western Sicily, $270 \mathrm{~km}$ north-east of the Cap Bon Promontory (Tunisia) and $230 \mathrm{~km}$ west of the Italian Peninsula (Fig. 1). The observation post was at the highest point (approx. $150 \mathrm{~m}$ ) of the promontory dominating the NE coast of the island (its highest point, inland, reaching about $250 \mathrm{~m}$ ). From that post it was possible to detect birds actually crossing the Tyrrhenian Sea and those stopping migration. To avoid replication of data we did not count birds stopping migration but only those crossing the sea and those roosting at the site only when they were not recorded the following morning. In addition, we took notes of the behaviour of migrating Black Kites there.

At the Strait of Messina observations were carried out between 27 March and 25 May 2004 from a post located along the continental coast of the Strait where the distance between Sicily and continental Italy is the narrowest (approx. $3 \mathrm{~km}$ ); in this area, each spring, the main passage of migrating raptors along the continental coast of the Strait has been reported (Agostini 1992, Agostini et al. 1994a, Agostini et al. 1994b, Agostini et al. 1995).

At both sites observations were made between $8.00 \mathrm{a} . \mathrm{m}$. to $18.00 \mathrm{p} . \mathrm{m}$. (solar time) for a total of 1200 hours of observations. We divided the 60 days of observation during 2002 and 2004 into six 10-day periods. Finally we divided aged birds into two age classes: immatures and adults (Forsman 1999).

\section{RESULTS}

At the island of Ustica the passage of 302 Black Kites was reported, mostly adults (87.1\%; aged birds $-N=37$ ). The timing did not show clear waves of passage (Fig. 2) while the passage of immature birds (12.9\% of the total) mostly occurred in the second half of the study period (Fig. 3). At this site Black Kites migrated mostly in flocks comprised on average of $6.9 \pm 0.8(S E)$ individuals (max. 24 in a flock). Having 


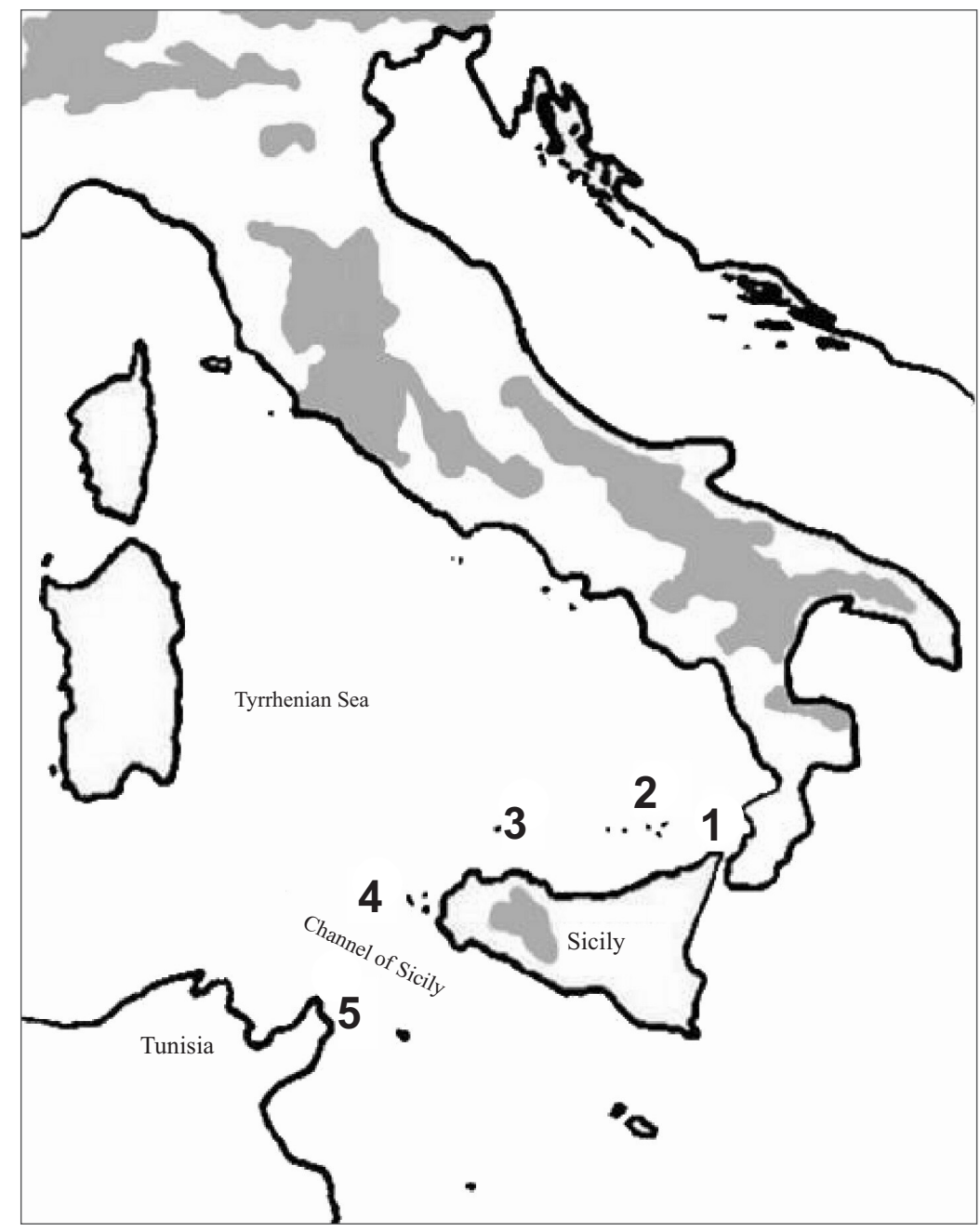

Fig. 1. Locations mentioned in the text (study sites in bold): 1 - Strait of Messina, 2 - Panarea and the Eolian islands, 3 - Ustica island, 4 - Marettimo island, 5 - Cap Bon Promontory. In grey - the main breeding grounds of Black Kites in central-southern Italy (Sergio 2002, Sarà 2003).

reached the coastline, Black Kites were more likely to stop migration (not crossing the sea and roosting at the site) rather than to cross the water (Table $1 ; \chi^{2}=7.8, d f=1$, $p<0.01$ ). A flock of 8 individuals was seen hunting and staying on the island for six days. In 35 cases, with a total of 105 individuals, we observed Black Kites reaching the coastline and then flying back inland. In 3 cases (for a total of 28 individuals) it was not possible to follow their movements. Finally, 179 Black Kites were observed disappearing over the sea toward NE, often hesitating along the coastline and in two cases crossing the water apparently following a Marsh Harrier (Circus aeruginosus). 

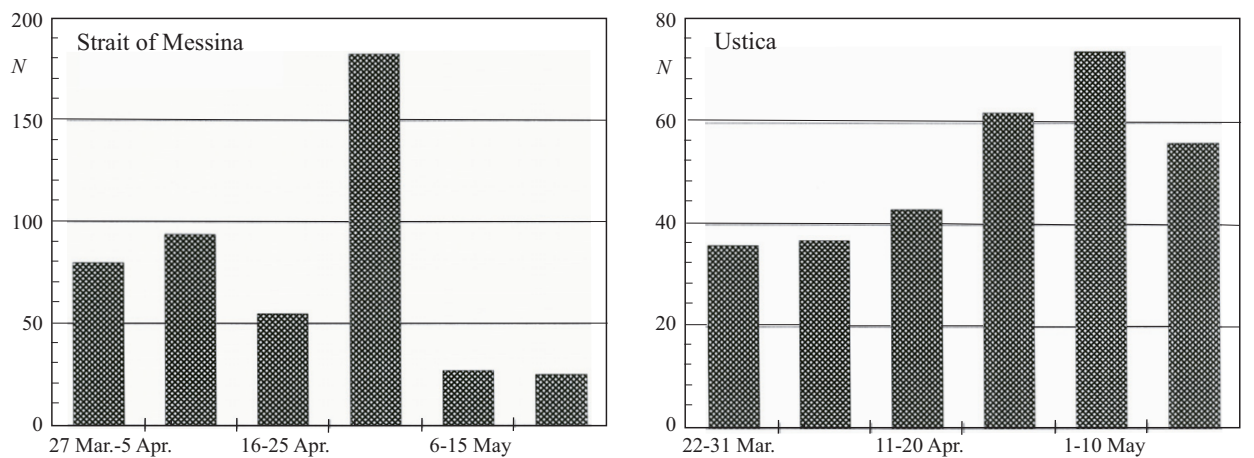

Fig. 2. The occurrence of Black Kites at the Strait of Messina (27 March - 25 May 2004) and at the island of Ustica (22 March - 20 May 2002) for every 10-day periods.

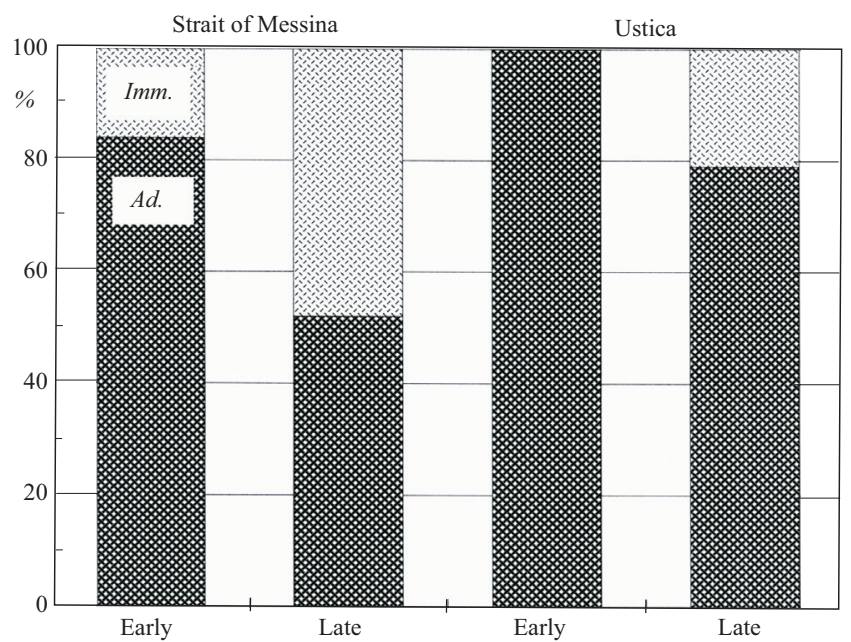

Fig. 3. Proportion of adult and immature Black Kites in the first (Early) and in the second (Late) month of observations.

Table 1

Migratory behaviour of Black Kites observed at the island of Ustica (22 March

- 20 May 2002). Number of records (flocks + solitary individuals), the total number of individuals and the percentage recorded for each behaviour are given.

\begin{tabular}{|l|c|c|c|}
\hline \multirow{2}{*}{} & Records & \multicolumn{2}{|c|}{ Individuals } \\
\cline { 2 - 4 } & $N$ & $N$ & $\%$ \\
\hline Crossing the sea & 38 & 179 & 40.2 \\
\hline Not crossing the sea & 35 & 105 & 23.6 \\
\hline Roosting & 13 & 132 & 29.8 \\
\hline Undetected direction & 3 & 28 & 6.4 \\
\hline
\end{tabular}


Altogether 459 individuals were observed at the Strait of Messina showing a bulk of movements between the last days of April and the beginning of May (Fig. 2) when the passage of 181 (41.2\%) Black Kites was reported (Fig. 2; max. one day count 67 on 1 May). In 53 cases it was possible to age migrants, $33(62.3 \%)$ of them were adults and $16(37.7 \%)$ - immature birds. Black Kites migrated mostly in small flocks comprising on average $3.7 \pm 0.2(S E)$ individuals (max. 10 in a flock) while 104 birds migrated one by one. Comparing the passage of Black Kites at the two sites, a higher proportion of birds migrating singly was recorded at the Strait of Messina (contingency table: $\chi^{2}=47.4, d f=1, p<0.01$ ).

\section{DISCUSSION}

During the present study hundreds of Black Kites migrated at each site mostly between the end of April and the beginning of May, when a significant percentage of immature birds was observed. Our results suggest that several non-breeders cross the Central Mediterranean during spring migration. Conversely, during autumn migration, Black Kites migrate following the peninsula and northern Sicily crossing the sea at the Channel of Sicily (max. 3600 over the island of Marettimo in 1998) peaking in late August, when mostly adults are observed (Agostini et al. 2000, Agostini et al. 2004, Panuccio et al. 2005, Panuccio et al. 2007).

The analysis of the water-crossing behaviour at the island of Ustica showed that Black Kites were reluctant to undertake the water-crossing. In addition, the higher percentage of Black Kites migrating in flocks at the island of Ustica than at the Strait of Messina confirms that these raptors tend to undertake long sea crossing mostly in flocks as previously reported at the Cap Bon Promontory (Tunisia; Agostini and Duchi 1994). Such as those observed over Ustica, at the Cap Bon Promontory Black Kites often stop migration facing the water barrier and fly back inland (Agostini 2002). In particular, at that site, Agostini and Duchi (1994) recorded a flock of 60 individuals (30 adults and 30 immatures) during the first half of May, which once reached the coastline split up - with adults crossing the sea and immatures flying back inland. Also in other species of raptors, e.g. the Marsh Harrier, non-breeders are more reluctant to cross water barriers and tend to remain at stopover sites longer than adults (Panuccio et al. 2004).

In agreement with previous studies made in the Central Mediterranean (Agostini 2002), during our observations Black Kites showing adult plumage were observed within the whole migration period. Black Kites reach their breeding sites in central Italy mostly in the second half of March (Battisti et al. 2003), and some individuals have been recorded starting breeding activities in late May (Chiavetta 1981, Panuccio and Canale 2003). It is interesting to report that during daily observations (from 27 February to 6 May 2009) at an important breeding site of central Italy (Castelporziano - Decima Malafede, 28-36 breeding pairs; De Giacomo et al. 2004) the first record of Black Kites was reported on 13 March, while main arrivals were observed starting from the $27^{\text {th }}$ of the month (Baldi, Dominicis, Pizzamiglio pers. comm.). For this reason it is not possible to exclude that Black Kites breeding in central, and perhaps 
southern Italy, show a different phenology of those breeding in other countries. Many of them could start their breeding activities some weeks later than the Spanish individuals observed migrating in early March through the Strait of Gibraltar (Finlayson 1992).

\section{ACKNOWLEDGEMENTS}

The fieldwork at the island of Ustica has been made on behalf of the Stazione di Inanellamento of Palermo, and funded by Assessorato Agricoltura e Foreste of Sicilian Region. We wish to thank Bruno Massa, Sarah De Marchi, Patrizia Bonelli and Emanuela Canale for their help at the site. Observations at the Strait of Messina were financed by NABU (Naturschutzbunde) and Hawk Mediterranean Foundation, in collaboration with the Migration Unlimited Network. We wish to thank for their help during observations: Christoph Hein, Antonino Morabito, Djamila Al Albouini, Elena Grasso, Heiko Menz, Andreas Quell, and Bianca Rau. Finally, we wish to thank RomaNatura Regional Authority and in particular Luca Marini, Alessia Baldi, Nicoletta Dominicis, Valentina Pizzamiglio, Raffaella Milani, Paolo Bedetti, Lucia Spirito, Luca Mangoni, Vittorio Castellana for the observations of arrival date of Black Kites at the breeding sites of Central Italy.

\section{REFERENCES}

Agostini N. 1992. Spring migration of Honey Buzzards (Pernis apivorus) at the Straits of Messina in relation to atmospheric conditions. J. Raptor Res. 26: 93-96.

Agostini N. 2002. La migrazione dei rapaci in Italia. In: Brichetti P,, Gariboldi A. (Eds). Manuale di Ornitologia. vol. 3. Edagricole-Il Sole 24 Ore, Bologna: pp. 157-182.

Agostini N. 2005. Are earlier estimates of Accipitriformes crossing the Channel of Sicily (Central Mediterranean) during spring migration accurate? J. Raptor Res. 39, 2: 184-186.

Agostini N., Duchi A. 1994. Water-crossing behavior of Black Kites (Milvus migrans) during migration. Bird Behav. 10: 45-48.

Agostini N., Logozzo D. 1998. Primi dati sulla migrazione primaverile dei rapaci Accipitriformi sull'isola di Marettimo (Egadi). Riv. ital. Orn. 68: 153-157.

Agostini N., Logozzo D., Morabito A., Mollicone D., Davani S., Pfister O. 1995. La migrazione primaverile dei rapaci Accipitriformi sullo Stretto di Messina. Avocetta 19: 73.

Agostini N., Logozzo D., Panuccio M. 2000. The island of Marettimo (Italy), important bird area for the autumn migration of raptors. Avocetta 24: 95-99.

Agostini N., Malara G. 1997. Entita delle popolazioni di alcune specie di Accipitriformi migranti, in primavera, sul Mediterraneo centrale. Riv. ital. Orn. 66: 174-176.

Agostini N., Malara G., Neri F., Mollicone D. 1994a. La migrazione primaverile del falco pecchiaiolo, Pernis apivorus, sullo Stretto di Messina: problemi di protezione. Riv. ital. Orn. 62: 187-192.

Agostini N., Malara G., Neri F., Mollicone D., Melotto S. 1994b. Flight strategies of Honey Buzzards during spring migration across the central Mediterranean. Avocetta 18: 73-76.

Agostini N., Panuccio M. 2010. Western Marsh Harrier (Circus aeruginosus) migration through the Mediterranean Sea: a review. J. Raptor Res. 44, 2: 136-142.

Agostini N., Premuda G., Mellone U., Panuccio M., Logozzo D., Bassi E., Cocchi L. 2004. Crossing the sea en route to Africa: autumn migration of some Accipitriformes over two central Mediterranean islands. Ring 26, 2: 71-78. 
Battisti C., Mari C., Tomassetti M., Zocchi A. 2003. La colonia suburbana di Nibbio bruno, Milvus migrans, a Roma: attivita riproduttiva e roosting premigratorio. Riv. ital. Orn. 73, 2: 97-103.

BirdLife International 2004. Birds in Europe: population estimates, trends and conservation status. BirdLife Conserv. Ser. 12.

Chiavetta M. 1981. I Rapaci d'Italia e d'Europa. Rizzoli, Milano.

De Giacomo U., Battisti C., Cecere C.J., Ricci S., Borlenghi S., Tinelli A. 2004. La popolazione romana di Nibbio Bruno (Milvus migrans): aspetti ecologici. In: Corsetti L. (Ed.). Uccelli rapaci nel Lazio: status e distribuzione, strategie di conservazione. Atti del Convegno, Sperlonga, 13 dicembre 2003. Ed. Belvedere, Latina: 95-124.

Finlayson C. 1992. Birds of the Strait of Gibraltar. T \& A D Poyser, London.

Forsman D. 1999. The Raptors of Europe and the Middle East. T \& A D Poyser, London.

Mellone U., Agostini N., Panuccio M., Gustin M. 2007. [Spring raptor migration over the Eolian archipelago.] Proc. XIV Ital. Ornithol. Congr.: 67. (In Italian).

Panuccio M., Agostini N., Massa B. 2004. Spring raptor migration at Ustica, southern Italy. Brit. Birds 97: 400-403.

Panuccio M., Agostini N. Mellone U. 2005. Autumn migration strategies of honey buzzards, black kites, marsh and Montagu's harriers over land and over water in the Central Mediterranean. Avocetta 29: 27-32.

Panuccio M., Agostini N., Lucia G., Mellone U., Ashton Booth J., Wilson S., Chiatante G., Todisco S. 2007. [The Serre Catanzaresi: Important Bird Area for the autumn migration of raptors.] Proc. XIV Ital. Ornithol. Congr.: 68. (In Italian).

Panuccio M., Canale E. 2003. Osservazioni sui movimenti post-riproduttivi del Nibbio bruno, Milvus migrans, nel Lazio (Central Italy). Riv. ital. Orn. 73: 180-182.

Sarà M 2003. The colonization of Sicily by the Black Kite (Milvus migrans). J. Raptor Res. 37, 2: 167-172.

Sergio F. 2002. Nibbio bruno Milvus migrans (Boddaert, 1783). In: Spagnesi M., Serra L. (Eds). Iconografia degli uccelli d'Italia. vol. 2. Istituto Nazionale per la Fauna Selvatica: pp. 8-9.

Zalles J., Bildstein K. 2000. Raptor watch: a global directory of raptor migration sites. BirdLife Conserv. Ser. 9. 